\title{
Discreto personagem do império brasileiro: Luís Pedreira do Couto Ferraz, visconde do Bom Retiro (1818-1886)
}

Begonha Bediaga*

\section{RESUMO}

Analisa a trajetória de Luís Pedreira do Couto Ferraz, visconde do Bom Retiro e personagem da alta governança do Segundo Reinado, que, a despeito de sua participação em política e administração durante mais de 40 anos, ainda é pouco referido na historiografia. Couto Ferraz foi presidente de duas províncias, deputado em diversas legislaturas, ministro no Gabinete da Conciliaçáo, senador e membro do Conselho de Estado, além de ter atuado na direçáo de diversas instituiçôes. Destaca-se seu papel de amigo e confidente de Pedro II e propóe-se que sua discrição buscava ao mesmo tempo preservar o monarca e garantir proximidade e influência no poder, muitas vezes de forma indireta e pouco perceptível.

Palavras-chave: Brasil; Segundo Reinado; trajetória biográfica; Luís Pedreira do Couto Ferraz; visconde do Bom Retiro.

\section{ABSTRACT}

This paper analyzes the trajectory of Luís Pedreira do Couto Ferraz, viscount of Bom Retiro, a high-ranking government official of the Second Reign, who is still seldom mentioned in the historiography, despite his participation in politics and the administration for more than 40 years. Couto Ferraz was president of two provinces, representative in several legislatures, minister in the Cabinet of Conciliation, senator and member of the State Council, besides being a director in several institutions. His role as a friend and confident of Pedro II is emphasized in the paper, which proposes that his discretion sought at the same time the preservation of the monarch, and the assurance of his own proximity to and influence in power, often in indirect and scarcely perceptible ways.

DOI - http://dx.doi.org/10.1590/2237-101X01803507

Artigo recebido em 26 de janeiro de 2017 e aprovado para a publicação em 4 de maio de 2017.

* Pesquisadora do Jardim Botânico do Rio de Janeiro. Rio de Janeiro - RJ, Brasil. E-mail: begonha.bediaga@ gmail.com.

Agradeço à Prof. ${ }^{\text {a }}$ Dra $^{\mathrm{a}}$. Adriana Pereira Campos, supervisora do meu pós doutorado na Universidade Federal do Espírito Santo/ Programa de Pós-Graduação em História/ PPGHIS, pelo incentivo no decorrer da pesquisa. À Fátima Argon, arquivista do Arquivo Histórico do Museu Imperial/IBRAM, que não mediu esforços em me auxiliar na busca dos documentos e no envio das fotocópias. E, por fim, à Regina Marques, pela leitura crítica e revisão do texto. 
Keywords: Brazil; Second Reign; Biographical Trajectory; Luís Pedreira do Couto Ferraz; viscount of Bom Retiro.

\section{RESUMEN}

El artículo analiza la trayectoria de Luís Pedreira do Couto Ferraz, visconde do Bom Retiro y personaje de alto nivel en el gobierno del Segundo Reinado, que, no obstante su participación en política y administración durante más de 40 años, es todavía poco referido en la historiografía. Couto Ferraz ha sido presidente de dos provincias, diputado en diversas legislaturas, ministro del Gabinete de Conciliación, senador y miembro del Consejo de Estado, además de haber actuado en la dirección de varias instituciones. Se destaca su papel de amigo y confidente de Pedro II y se propone que su discreción buscaba, al mismo tiempo, preservar el monarca y garantizar proximidad e influencia en el poder, muchas veces de manera indirecta y poco perceptible.

Palabras clave: Brasil; Segundo Reinado; trayectoria biográfica; Luís Pedreira do Couto Ferraz; visconde do Bom Retiro.

A vida de cada homem é feita de infinitos momentos, estados de espírito, pensamentos e sonhos que desaparecem no poço sem fundo e sem luz do tempo. Tudo o que podemos fazer é tentar reencontrar, com a ajuda das cartas, dos escritos, dos documentos e dos testemunhos que possuímos, alguns fragmentos da vida daquele a quem desejamos livrar do esquecimento. (Maurizio Viroli, O sorriso de Nicolau, São Paulo, Estação Liberdade, 2002, p. 111)

\section{Introdução}

As conexões entre indivíduo e conjuntura histórica devem ser compreendidas como trajeto de mão dupla, no qual o personagem interfere na realidade a partir de suas opçóes pessoais e o contexto histórico, por sua vez, intervém diretamente nas opções do indivíduo. Segundo Priore,

A reabilitação da biografia histórica integrou as aquisições da história social e cultural, oferecendo aos diferentes atores históricos uma importância diferenciada, distinta, individual. Mas não se 
tratava mais de fazer, simplesmente, a história dos grandes nomes, em formato hagiográfico quase uma vida de santo - , sem problemas nem máculas. Mas de examinar os atores (ou o ator) célebres ou não, como testemunhas, como reflexos, como reveladores de uma época. ${ }^{1}$

Sabina Loriga ${ }^{2}$ mostra que a desconfiança da historiografia em relação ao estudo das trajetórias individuais tem diminuído à medida que se busca a significação histórica de um personagem também como uma forma de compreender o contexto. Ao defender que o historiador volte a trabalhar nas biografias, a autora assegura que a tarefa pode ser "a ocasião de apreender a densidade social de uma vida", ${ }^{3}$ mas ressalta: o "que está em jogo para o historiador não reside nem no geral nem no particular, mas em sua conexão".

Com a intenção de inserir Luís Pedreira do Couto Ferraz no cenário do Segundo Reinado, porém distante de apresentá-lo numa abordagem heroificada, busco contribuir para o entendimento do contexto do período. A análise de sua personalidade e trajetória colabora para o entendimento da cultura política daqueles tempos, ajuda a lançar luz sobre as ideias, aspiraçóes e outras expressóes que ele conjugava com seu grupo social, contribuindo assim para a sua elucidação.

É possível localizar informações sobre Couto Ferraz em artigos da história da educação, medicina, imigração, entre outras áreas, contudo tais reflexóes apenas apresentam dados biográficos sobre o personagem e o associam com o tema em estudo, baseando-se sobretudo em referências obtidas em Sacramento Blake e Sisson. ${ }^{5}$ Em parte, as poucas referências ao personagem na historiografia justificam-se por sua personalidade tímida e discreta, traduzida em uma vida social reclusa e na parcimônia no uso da tribuna para pronunciamentos. Acresce-se ainda a inexistência de documentos guardados por Couto Ferraz e existem indícios de que seus documentos pessoais teriam sido descartados intencionalmente. Raffard menciona a existência de uma correspondência expressiva de Pedro II entre os papéis de Bom Retiro, eliminada post mortem por sua família em atendimento a um desejo explícito do visconde. ${ }^{6}$

Identifiquei a presença de Couto Ferraz em outros arquivos, uma vez ter sido ele um missivista contumaz. Felizmente estão preservadas inúmeras de suas cartas enviadas a Pedro II, José Maria da Silva Paranhos (visconde do Rio Branco), Pedro de Araújo Lima (marquês de Olinda) e José Thomaz Nabuco de Araújo, entre outros. A maior parte desses documentos

\footnotetext{
${ }^{1}$ DEL PRIORE, Mary. Biografia: quando o indivíduo encontra a história. Topoi. Revista de História, Rio de Janeiro, v. 10, n. 19, p. 7-16, 2009. p. 9.

${ }^{2}$ LORIGA, Sabina. O pequeno X: da biografia à história. Belo Horizonte: Autêntica, 2011.

${ }^{3}$ Ibidem, p. 219.

${ }^{4}$ Ibidem, p. 230.

${ }^{5}$ Respectivamente: SACRAMENTO BLAKE, Augusto Victorino Alves. Dicionário bibliográfico brasileiro. Rio de Janeiro: Imprensa Nacional, 1902. 7 v.; SISSON, Sebastién Auguste. Galeria dos brasileiros ilustres. Brasília, DF: Senado Federal, 1999.

${ }^{6}$ RAFFARD, Henri. Apontamentos acerca de pessoas e cousas do Brasil. Revista do Instituto Histórico e Geográfico Brasileiro, Rio de Janeiro, t. 61, parte 2, p. 438, 1899. p. 438.
} 
encontra-se em arquivos sob custódia do Museu Imperial, do Instituto Histórico e Geográfico Brasileiro, da Biblioteca Nacional e do Arquivo do Itamaraty. Por se tratar quase sempre de cartas enviadas por Couto Ferraz, não é possível acompanhar os diálogos travados com os remetentes por meio de correspondência. De todo modo, elas são reveladoras de sua atuação no que expressam de sua rede de sociabilidades e de acordos, troca de favores, desafetos e posiçóes políticas. Ainda entre as fontes primárias consultadas, recorri a periódicos da época e a documentos oficiais como relatórios de presidentes de províncias e ministro dos Negócios do Império.

A principal fonte secundária utilizada na pesquisa foi a biografia de José Thomaz Nabuco de Araújo, escrita por seu filho Joaquim Nabuco, ${ }^{7}$ uma vez que Couto Ferraz esteve presente em diversos eventos do Segundo Reinado nela narrados. O autor apresenta as posiçóes políticas e pessoais de Bom Retiro e a visão que dele se tinha na época, em uma interpretação peculiar de quem conviveu com o personagem.

\section{Trajetória do personagem}

Natural da cidade do Rio de Janeiro, Luís Pedreira do Couto Ferraz nasceu em 1818, filho de um desembargador de mesmo nome, ${ }^{8}$ que paralelamente à carreira jurídica foi deputado suplente pela Bahia na Assembleia Constituinte de 1823 e exerceu mandato na Câmara dos Deputados de 1826 a 1829. Pertencente à elite imperial, a família frequentava o palácio do imperador e quando crianças Luís Pedreira do Couto Ferraz e seu irmão João ali brincaram com o futuro imperador Pedro II. ${ }^{10}$

Seu pai faleceu em 1831 como desembargador dos Agravos da Casa da Suplicaçáo do Rio de Janeiro, deixando viúva — Guilhermina Amália Correia Pedreira - e seis filhos. ${ }^{11}$ Cinco anos depois, com a morte da mãe, Couto Ferraz assumiu a educação dos irmãos. Mais tarde demonstraria orgulho por ter auxiliado o irmão João a se tornar secretário do Supremo Tribunal de Justiça e por ter casado as quatro irmãs. Ele mesmo nunca casou. Mantinha uma vida discreta em uma residência no Engenho Novo, a Quinta do Bom Retiro, e em outra na Floresta da Tijuca com o sugestivo nome de Sítio da Solidão, ambas no Rio de Janeiro.

\footnotetext{
${ }^{7}$ NABUCO, Joaquim. Um estadista do império. Rio de Janeiro: Topbooks, 1997.

${ }^{8}$ SISSON, Sebastién Auguste. Galeria dos brasileiros ilustres, op. cit., p. 199.

${ }^{9}$ Respectivamente: BRASIL. Congresso. Câmara dos Deputados. Centro de Documentaçáo e Informação. Nominata de deputados brasileiros constituintes: 1823. [Brasília], s.d. (folhas datilografadas). BRASIL. Congresso. Câmara dos Deputados. Centro de Documentação e Informação. Nominata de deputados brasileiros 1ª Legislatura: [Império]: 1826-1829. [Brasília], s.d. (folhas datilografadas).

${ }^{10}$ LYRA, Heitor. História de dom Pedro II: 1825-1891. Belo Horizonte: Itatiaia, 1977.

${ }^{11}$ BRASIL. Coleção de Leis. Decreto n. 64 de 22 de outubro de 1836, determina que a pensão concedida em 1834, seja dividida entre os seis filhos do desembargador Luís Pedreira do Couto Ferraz.
} 
Em uma época em que a maioria dos políticos do império era composta por proprietários rurais, com terras adquiridas por herança ou casamento, Couto Ferraz garantiu sua sustentação econômica acumulando atividades intelectuais, políticas e administrativas. Formado em Direito pela Faculdade de Sáo Paulo, foi logo nomeado lente substituto da mesma faculdade em 1838. ${ }^{12}$ Poucos anos depois, em 1844, iniciava a carreira política como deputado para a Câmara Provincial do Rio de Janeiro. ${ }^{13}$ Em 1845 assumiu a vice-presidência da província do Rio de Janeiro ${ }^{14}$ por indicação do próprio presidente, Aureliano de Souza Coutinho, ${ }^{15}$ que se afastara do cargo naquele período para cumprir seu mandato de deputado geral.

Um ano depois, em 1846, assumiu o cargo de presidente da província do Espírito Santo, decerto a nomeação foi obtida sob influência e apoio de Souza Coutinho e com a aquiescência do monarca. José Murilo de Carvalho observa a importância desse posto para a ascensão na política imperial:

Uma vez dentro da Câmara, estava-se a um passo do círculo interno da elite, ao qual se tinha acesso por uma combinação de capacidade e patronato, exercendo o imperador o papel ativo na seleção. A entrada no clube se dava pela nomeação para um posto ministerial ou uma presidência de província. ${ }^{16}$

Entre as realizações de Couto Ferraz à frente da presidência da província capixaba, destaca-se a criação da primeira colônia de povoamento com imigrantes alemães no Espírito Santo, a Colônia de Santa Isabel, na atual cidade de Domingos Martins. Também empenhou-se na catequização dos indígenas, com a intenção de diminuir o temor de "ataques" por parte da população e incorporar aqueles indivíduos ao convívio social. A respeito da iniciativa, ressaltou em relatório: "Serão tantos braços úteis que, bem dirigidos e aproveitados, aumentarão a população livre, e entregues à indústria, poder-nos-ão servir de grande recurso à lavoura e às artes." ${ }^{\prime 17}$ Ambos os projetos estavam em consonância com o Estado imperial, que buscava alternativas à escassez de mão de obra escrava diante da iminente proibição do tráfico.

${ }^{12}$ NOGUEIRA, Almeida. A academia de São Paulo: tradições e reminiscências. São Paulo: [Typographia Vanorden], 1907. v. 1; p. 61; SACRAMENTO BLAKE, Augusto Victorino Alves, Dicionário bibliográfico brasileiro, op. cit., p. 447; Biblioteca Nacional. Seção de Manuscritos: "Requerimento encaminhado ao Ministério do Império, solicitando ser nomeado para uma das cadeiras vagas na academia de São Paulo”, 1839. Localização: C-0478,015, n. 001

${ }^{13}$ Jornal do Comércio, 29/11/1844. Disponível em: <http://memoria.bn.br/DocReader/364568_03/7065>. Acessso em: 9 out. 2016.

${ }^{14}$ LACOMBE, Lourenço Luiz. Os chefes do executivo fluminense. Petrópolis, RJ: Museu Imperial, 1973, p. 20. ${ }^{15}$ Membro do Partido Conservador e líder da chamada facção áulica, conhecida pela influência no então jovem imperador Pedro II.

${ }^{16}$ CARVALHO, José Murilo de. A construção da ordem: a elite política imperial. Rio de Janeiro: UFRJ/ Relume-Dumará, 1996, p. 111.

${ }^{17}$ Relatório do presidente da província do Espírito Santo, o doutor Luiz Pedreira do Couto Ferraz, na abertura da Assembleia Legislativa Provincial no dia 23 de maio de 1847. Rio de Janeiro, Typ. do Diário de N. L. Vianna, 1848, p. 30. 
Outra área a que Couto Ferraz deu especial atenção foi a educação, com a criação do "Regulamento das escolas de primeiras letras da província do Espírito Santo". ${ }^{18}$ Com ele, o governo tomava para si a responsabilidade da instrução, por meio de medidas como inspeção das escolas, habilitação dos professores, definição das disciplinas a serem adotadas, escolha de material didático e definição de carga horária de ensino.

Uma matéria assinada pela Assembleia Legislativa do Espírito Santo, publicada em um periódico da Corte, ${ }^{19}$ manifestava o apoio ao governo de Couto Ferraz pelos deputados da província, que não lhe poupavam elogios e se declaravam preocupados com a possibilidade de ele ser nomeado para presidência de outra província, uma prática comum na época. $\mathrm{O}$ reconhecimento a seu governo também pode ser avaliado pelas duas vitórias que obteve nas eleiçóes para deputado geral pelo Espírito Santo, em 1848 e $1850 .{ }^{20}$ Nas legislaturas seguintes, de 1853 a 1863, elegeu-se deputado pela província do Rio de Janeiro. ${ }^{21}$

Couto Ferraz retirou-se do governo do Espírito Santo para assumir a presidência da província do Rio de Janeiro em 1848, e em cinco anos no cargo deixou mais uma vez sua marca no ensino, ao implantar o "Regulamento da instrução primária na província do Rio de Janeiro", que ordenava a execução de reformas à semelhança daquelas anteriormente promulgadas para o Espírito Santo. ${ }^{22}$

Segundo Nabuco, ao concluir seu mandato na província fluminense Couto Ferraz gozava de boa fama como administrador, porém não demonstrava paixóes partidárias:

Pedreira [como lhe chamavam os mais próximos], ministro do Império, trazia da presidência do Rio de Janeiro a reputação de um espírito renovador, ansioso por introduzir em nosso país os

\footnotetext{
${ }^{18}$ Arquivo Público do Espírito Santo. Livro das Leis do Espírito Santo. "Regulamento das escolas de primeiras letras da província do Espírito Santo, promulgado em 20 de fevereiro de 1848 e aprovado provisoriamente pela Lei n. 6 de maio do mesmo ano".

${ }^{19}$ Diário do Rio de Janeiro. Rio de Janeiro, 23 de junho de 1847, p. 2. Disponível em: <http://memoria.bn.br/ DocReader/cache/895608108287/I0031268-2Alt=002462Lar=001528LargOri=004224AltOri=006806. JPG>. Acesso em: 27 out. 2016,

${ }^{20}$ Respectivamente: BRASIL. Congresso. Câmara dos Deputados. Centro de Documentação e Informação. Nominata de deputados brasileiros $7^{a}$ Legislatura: Império: 1848. [Brasília], s.d. (folhas datilografadas). BRASIL. Congresso. Câmara dos Deputados. Centro de Documentação e Informação. Nominata de deputados brasileiros 8a Legislatura: Império: 1849-1852. [Brasília], s.d. (folhas datilografadas).

${ }^{21}$ Respectivamente: BRASIL. Congresso. Câmara dos Deputados. Centro de Documentação e Informação. Nominata de deputados brasileiros 9 ${ }^{a}$ Legislatura: Império: 1853-1856. [Brasília], s.d. (folhas datilografadas). ${ }^{22}$ Chama atenção a longa duração de seu mandato, se comparada à média de um ano e cinco meses dos mandatos dos presidentes na época (cf. Carlos P. Corrêa. A presidência de província no império, ANPUH XXII Simpósio Nacional de História, João Pessoa, 2003). Sobre o regulamento, ver GONDRA, Jorge Gonçalves; TAVARES, Pedro Paulo Hausmann. A instruçáo reformada: açôes de Couto Ferraz nas províncias do Espírito Santo, Rio de Janeiro e na Corte Imperial. CONGRESSO BRASILEIRO DE HISTÓRIA DA EDUCAÇÃO, 3.: A EDUCAÇÃO ESCOLAR EM PERSPECTIVA HISTÓRICA, 2004, Curitiba. Anais. Curitiba: Adivan High Tech Tecnologia Digital, 2004. v. 1. e GAUDIO, Eduardo Vianna. Couto Ferraz e os regulamentos de educaçáo na província do Espírito Santo - 1848 e 1861. VIII CONGRESSO BRASILEIRO DE HISTÓRIA DA EDUCAÇÃO, 2015, Maringá. Anais.
} 
grandes melhoramentos modernos (...). Era um administrador de uma mobilidade infatigável, que mexia em tudo, e entendia de tudo, reformador de instinto. (...) amigo dos últimos aperfeiçoamentos em tudo, conhecendo e acompanhando as modificações introduzidas nos serviços públicos dos países mais adiantados, era um auxiliar de primeira ordem num governo reformista. ${ }^{23}$

No lastro da boa reputação que gerou na Corte, decorrente sobretudo da implantação da reforma de ensino no Espírito Santo e no Rio de Janeiro, Couto Ferraz foi convidado para assumir a pasta dos Negócios do Império no Gabinete de Honório Hermeto Carneiro Leão, ${ }^{24}$ conhecido como Gabinete da Conciliação e considerado, por muitos, fundamental na consolidação do reinado de Pedro II. Ultrapassava assim as fronteiras das províncias que presidira para influenciar todo o império. Ao que tudo indica, foi o ministro que mais tempo permaneceu nessa pasta e nos quase quatro anos (1853-1857) em que a ocupou foi responsável pela maioria das nomeaçóes do governo central: dos presidentes da província aos cargos da polícia, higiene pública, instrução elementar e superior, entre outras.

Nas Instruçóes que o imperador entregou ao presidente do Conselho de Ministros Carneiro Leão em 1853, em que constavam os itens a serem contemplados no programa de governo, dez deles eram elencados para a pasta dos Negócios do Império, entre os quais um relativo à reforma do ensino, em que Pedro II escreveu apenas: "da instrução primária e secundária (o trabalho já está quase feito e parte dele jaz em meu poder)” ${ }^{25}$ O projeto de Couto Ferraz estava definido e já havia sido testado nas províncias capixaba e fluminense e em consonância com os propósitos da Coroa.

Assim, apenas cinco meses após assumir o ministério foi aprovado o "Regulamento da instrução primária e secundária do Município da Corte”, conhecida como Reforma Couto Ferraz, a primeira de organização e controle da instrução primária e secundária no Brasil. Sobre ela, Pontes afirma: "a Reforma Couto Ferraz representou não somente o início de um processo de institucionalização da instrução primária e secundária, mas também a consolidação do Estado imperial como promotor e regulador desse processo" ${ }^{26}$

De fato, Couto Ferraz já tinha então certa expertise no assunto. Participara das discussões acerca da necessidade de reformas no ensino desde o seu início, na década de 1840, quando

\footnotetext{
${ }^{23}$ Nabuco, Joaquim. Um estadista do império, op. cit., p. 166-167.

${ }^{24}$ Honório Hermeto Carneiro Leão (1801-1856), visconde e, mais tarde, marquês do Paraná, foi presidente do Conselho de Ministros e ministro da Fazenda de 1853 a 1856, quando faleceu.

${ }^{25}$ Apud FERRAZ, Paula Ribeiro. O Gabinete da Conciliação: atores, ideias e discursos (1848-1857). Dissertação (mestrado em História) — Programa de Pós-Graduação em História, Universidade Federal de Juiz de Fora, 2013. O parêntesis encontra-se no original. Notação: Instruçôes do imperador dadas ao ministério organizado pelo marquês de Paraná, 6-9-1853. Biblioteca Nacional, Seção de manuscritos.

${ }^{26}$ PONTES, Vinicius Liorde. A Reforma Couto Ferraz e o estabelecimento de uma direção para a instrução primária e secundária no Império do Brasil. Dissertação (mestrado) - Departamento de História, Pontifícia Universidade Católica, Rio de Janeiro, 2009, p. 113
} 
obteve aprovação de um projeto apresentado em conjunto com Justiniano José da Rocha, ${ }^{27} \mathrm{e}$ aprofundara-se na questáo quando esteve na presidência de duas províncias e nelas implantou reformas da mesma natureza.

Estudiosos sobre as reformas da educação no Brasil são unânimes em apontar a Reforma Couto Ferraz como marco da intervenção explícita do Estado na instrução pública e nos estabelecimentos particulares. Seu objetivo principal era promover a melhoria do magistério por meio da implantação de concurso público e outras exigências para o exercício do ofício. Por outro lado, previa benefícios com o propósito de tornar a profissáo atraente e concorrida, a exemplo do direito à aposentadoria, pouco usual na época.

A Reforma Couto Ferraz era restrita à Corte, uma vez que a legislação outorgava ao governo das províncias a regulação da instrução pública. Porém, conforme Castanha, ${ }^{28}$ as inovações de Couto Ferraz foram aos poucos incorporadas no país. Era mesmo evidente a intenção de que a reforma na Corte servisse de exemplo às províncias e a elas fosse estendida, atendendo à ambição imperial de unificar e controlar a instrução e assim formar os indivíduos em consonância com um projeto de civilização semelhante ao da Europa.

Também para Castanha, a Reforma foi o principal projeto referente à instrução pública, no império:

Não há como negar a importância da Reforma Couto Ferraz no processo de organização da instrução pública no Brasil Imperial, e da mesma forma o papel desempenhado por ele Ferraz naquele processo. Ligado ao Partido Conservador, procurou colocar a instrução a serviço do projeto político defendido por seu grupo. ${ }^{29}$

O autor fundamenta a afirmação de que a Reforma Couto Ferraz estava sintonizada com o projeto do Partido dos Conservadores, destacando que os dois primeiros inspetores gerais de Instruçáo Primária eram membros da chamada Trindade Saquarema: José Rodrigues Torres e Eusébio de Queiróz Mattoso da Câmara, que esteve no posto por oito anos. Ressalta ainda a função prioritariamente política desse cargo, tendo em vista ser-lhe vedada a nomeação de professores e diretores de escolas públicas ou particulares, ${ }^{30}$ e conclui que somente os saquaremas, grupo coeso e com a autoridade necessária, seriam capazes de pôr em prática os princípios de centralização e hierarquização do império. ${ }^{31}$

\footnotetext{
${ }^{27}$ BRASIL. Coleção de leis. Decreto n. 630 de 17/9/1851.

${ }^{28}$ CASTANHA, André P. O Ato Adicional de 1834 e a instruçâo elementar no império: descentralização ou centralização? Tese (doutorado) — Universidade de São Carlos, São Carlos, 2007, p. 128.

${ }^{29}$ Ibidem, p. 156

${ }^{30}$ Ibidem, p. 157.

${ }^{31}$ Observemos, também, com Ilmar Mattos, a relevância da administração da província fluminense para os projetos do império: “ (...) a província fluminense cumprindo o papel de um laboratório, no qual os Saquaremas tanto testavam medidas e avaliavam açóes que buscavam estender à administração geral, quanto aplicavam decisóes do Governo-Geral, sempre com a finalidade última de consolidar a ordem no Império.” MATTOS, Ilmar Rohloff de. O tempo Saquarema. São Paulo: Hucitec, 1994, p. 240.
} 
Ainda no campo da instrução pública, o ministro Couto Ferraz desempenhou importante papel na criação do Imperial Instituto dos Meninos Cegos e do Imperial Instituto dos Surdos-Mudos. No ensino superior, implantou novos estatutos para as faculdades de Direito e de Medicina e para a Academia de Belas-Artes e o Conservatório de Música.

Quanto às reformas na Faculdade de Medicina, Edler aponta que suas principais motivaçôes foram o projeto centralizador do império e o propósito de controlar a vida acadêmica:

Os Estatutos de 1854 opunham-se ao Regimento que criara as faculdades de Medicina em 1832, tal como a fase de consolidação do Segundo Reinado opunha-se àquela das Regências. Todas as teses autonomistas contidas na lei de 3 de outubro tinham seu contraponto no decreto de 28 de abril de 1854, de autoria do Ministro do Império, Barão do Bom Retiro. Embora alterando em alguns pontos, o projeto que tramitava no Parlamento mantinha no fundamental as mesmas inspiraçóes políticas: a Faculdade perdia sua autonomia e ao longo de 30 anos esteve submetida a um regime de absoluta subordinação aos diferentes gabinetes do Segundo Reinado. ${ }^{32}$

A atuação de Couto Ferraz à frente do Ministério dos Negócios do Império revela também sintonia com o grupo que gravitava em torno das atividades científicas e que reivindicava do governo a realização de expediçóes nacionais, cujo objetivo era obter um inventário do país elaborado pelos próprios brasileiros. Ao indicar, em relatório ministerial, as "Instruçóes para a Comissão Científica encarregada de explorar o interior de algumas províncias do Brasil”, Couto Ferraz afirmou: "[atribuo] a maior importância a essa comissão, convencido de que vai preencher uma lacuna que há muito sentíamos. Seus resultados compensarão largamente os sacrifícios que forem feitos." 33

Outra iniciativa sua relacionada com as ciências foi assinalada por Lopes, que identificou em documentos do Museu Nacional ordens do ministro para que o material paleontológico encontrado no Crato (Ceará) fosse enviado ao Rio de Janeiro; e, “com disposição pouco usual ao longo da história do Museu Nacional, continuava autorizando as despesas necessárias para as buscas e transporte dos materiais". ${ }^{34}$

Couto Ferraz teve atuação decisiva em outros campos, a exemplo da criação da Floresta da Tijuca, na cidade do Rio de Janeiro, conforme analisa Pádua:

\footnotetext{
${ }^{32}$ EDLER, Flavio Coelho. As reformas do ensino médico e a profissionalização da medicina da corte do Rio de Janeiro: 1854-1884. Dissertação (mestrado) - Departamento de História, Universidade de São Paulo, São Paulo, 1992, p. 40.

${ }^{33}$ Luís Pedreira do Couto Ferraz, Relatórios apresentados à Assembleia Geral Legislativa pelo ministro e secretário de Estado dos Negócios do Império, RJ, 1856. In: LOPES, Maria Margaret. O Brasil descobre a pesquisa cientifica: os museus e as ciências naturais no século XIX. São Paulo: Hucitec, 2009, p. 137.

${ }^{34}$ Ibidem, p. 116. Tal recolhimento se deu com a colaboraçáo dos magistrados locais, devido à ausência de naturalistas na região.
} 
Ao contrário do que muitos pensam, a iniciativa não foi decisão pessoal de Pedro II e, sim, de alguns intelectuais e políticos que faziam parte de seu círculo de amizades. É o caso de Luís Pedreira do Couto Ferraz, que, quando ocupava a posição de Ministro do Império, entre 1854 e 1856, deu início às desapropriaçóes dos terrenos necessários ao reflorestamento. Mais tarde, na condição de presidente do Imperial Instituto Fluminense de Agricultura, Couto Ferraz acompanhou e apoiou as etapas iniciais do programa de reflorestamento, que foram dirigidas pelo Major Archer, entre 1862 e $1874 .{ }^{35}$

Mesmo após se afastar do Ministério do Império, Couto Ferraz continuou um entusiasta do potencial da preservação das florestas, como atesta uma carta sua a Pedro II, de 1874, em que se manifestava preocupado com a oferta de emprego feita por um fazendeiro ao major Manoel Gomes Archer, administrador e responsável pelo reflorestamento do Maciço da Tijuca:

(...) tudo provém da demora da reforma do serviço florestal, ou antes de uma verdadeira organização, que permitindo o desenvolvimento do mesmo serviço com vantagem real para o Brasil ministre ao empregado [major Archer] zeloso, inteligente, e hoje verdadeira e única especialidade neste gênero, entre nos meios de decente subsistência, e consideração correspondente ao muito que faz, e tem feito. Se se realizar a outra hipótese [a demissão de Archer] — veremos em poucos anos desaparecer a floresta nacional da Tijuca, como desapareceu a começada nas Paineiras. (...) e um diretor de floresta não se improvisa.

A pronta reforma do estabelecimento, e a organização a que me refiro - talvez salvem ainda o desaparecimento do que tanto tem custado e que está tão bonito e é tão apreciado dos nacionais que ali tem ido, e principalmente dos estrangeiros que frequentam o lugar (...). Desde o tempo de Itaúna [ministro da Agricultura em 1872] existe ou deve existir no ministério um projeto que formulei e V.M.I. Viu e Examinou. ${ }^{36}$

Para concluir sobre as realizaçóes de Couto Ferraz como ministro, vale salientar o primeiro contrato para serviço de esgoto na Corte; a execução da Lei de Terras; a reforma eleitoral que dividiu o império em distritos eleitorais; o combate à epidemia da cólera morbus; o contrato para construção das vias férreas de Pernambuco, Bahia e São Paulo; os contratos das linhas férreas para o Jardim Botânico e a Tijuca, na Corte, além da abertura da estrada União e Indústria.

\footnotetext{
${ }^{35}$ PÁDUA, José Augusto. Flora e nação. In: MARTINS, Ana Cecília (Org.). Flora brasileira: história \& arte \& ciência. Rio de Janeiro: Casa da Palavra, 2009, p. 92-128. p. 114-115. Este autor discorre sobre o assunto também em Um sopro de destruição: pensamento político e crítica ambiental no Brasil escravista, 1786-1888. Rio de Janeiro: Zahar, 2002, p. 221-225.

${ }^{36}$ Museu Imperial. Arquivo Histórico. Arquivo POB, maço 169, doc. 7741. Carta de Luís Pedreira do Couto Ferraz a d. Pedro II, de 21/2/1874.
} 
No mesmo ano em que deixou o cargo de ministro, Couto Ferraz foi nomeado inspetor geral da Caixa de Amortização, ${ }^{37}$ função que exerceu até a sua aposentadoria, em 1877. Nunca retornou às aulas na Faculdade de Direito em São Paulo, não obstante ter sido designado lente catedrático da cadeira de Economia Política dois anos após deixar o cargo de ministro. ${ }^{38}$ Ambas as nomeaçóes apontam para o prestígio que adquiriu e para a garantia de sua carreira no Estado.

Quanto à vida partidária, Couto Ferraz fora eleito deputado sucessivamente de 1844 até a legislatura de 1861. Na eleição de 1863 não conseguiu se eleger, decerto pela derrocada do Partido Conservador. Empenhou-se, então, na disputa por uma vaga de senador pelo Rio de Janeiro e, uma vez eleito, foi nomeado pelo imperador na lista tríplice, em 1867.

\section{O alter ego de Pedro II}

Sergio Buarque de Holanda refere-se a Couto Ferraz como alter ego do imperador, ${ }^{39}$ expressão que parece definir à perfeição nosso personagem, sobretudo a partir da década de 1860. A timidez, ${ }^{40}$ somada às dificuldades para enfrentar o embate político na Câmara, que se acirrara com a criação da Liga Progressista, parece ter aproximado cada vez mais Couto Ferraz a Pedro II e o distanciado da vida partidária.

A amizade com o monarca iniciara ainda na meninice e o vínculo que os manteve unidos na idade adulta pode ter-se consolidado durante a viagem que fizeram às províncias do Norte, em 1859. Contudo, tais laços de estima devem ser atribuídos principalmente às semelhanças de gostos e maneiras de ser e agir. Nabuco refere-se a Couto Ferraz pelo sobrenome Pedreira, como o fazia Pedro II, e explica as semelhanças entre ambos:

O Imperador e Pedreira eram feitos para se entenderem, tinham a mesma moderação, a mesma prudência, os mesmos processos de conservação e melhoramento, a mesma arte de deixar as dificuldades resolverem-se por si mesmas evitando somente agravá-las, o mesmo respeito à opinião, as mesmas simpatias e deferências, quase os mesmos gostos e apreço pelas mesmas pessoas. ${ }^{41}$

\footnotetext{
${ }_{37}$ Jornal do Comércio, 11/12/1857. Disponível em: <http://memoria.bn.br/DocReader/364568_04/12230>. Acesso em: 29 set. 2016.

${ }^{38}$ Jornal do Comércio, 19/5/1858. Disponível em: <http://memoria.bn.br/DocReader/364568_04/12857>. Acesso em: 29 set. 2016.

${ }^{39}$ HOLANDA, Sergio Buarque de. Capitulos de história do império. São Paulo: Companhia das Letras, 2010, p. 151.

${ }^{40}$ Poucas vezes fez uso da tribuna para pronunciamentos e, segundo Nabuco (Um estadista do império, op. cit. 1997, p. 166), "apesar de possuir grande abundância de expressão e clareza de ideias, tinha um medo invencível da tribuna e para obrigá-lo a tomar a palavra os colegas recorriam a toda espécie de ardis".

${ }^{41}$ Ibidem, p. 167.
} 
Com a proximidade cada vez maior com o monarca, Couto Ferraz passou a ser, antes de tudo, ligado "a um terceiro partido, neutro, eclético, que se poderia chamar de Moderador, em conformidade com os interesses, as tendências, as peculiaridades da posição do Monarca”. ${ }^{42}$ Barman concorda com Nabuco quanto à opção de Couto Ferraz em se alijar da política: "Bom Retiro era suficientemente perspicaz e abnegado para saber que a intimidade com Pedro II impunha não voltar a se tornar ministro (...)."43

Por certo os quase vinte anos em que permaneceu na política, com boa reputação entre os pares e ocupando cargos relevantes no governo, facilitaram a Couto Ferraz o acesso ao palácio do monarca, o que lhe outorgava status e prestígio. Portanto não surpreende ele ter sido nomeado, em 1866, membro do Conselho de Estado Extraordinário e ratificado no Conselho de Estado Ordinário em $1871 .^{44}$

Uma vez nos cargos vitalícios de senador e conselheiro de Estado, Couto Ferraz não precisava mais enfrentar os conflitos habituais da vida político-partidária. "O Senado não faz política; não se deve envolver na política do dia; constituindo um partido", diria Nabuco de Araújo. ${ }^{45}$ Do mesmo modo as atividades do Conselho de Estado não deveriam transparecer um caráter político. Para Martins, essa instituição "se justificava no discurso administrativo por excelência, no ilimitado amparo da lei, nos esforços de aproximação das dissidências, na prática quase cotidiana da negociação, nas alianças que obedeciam a uma estratégia maior de segurança e estabilidade". 46

O título nobiliárquico foi concedido em 1867, primeiramente como barão do Bom Retiro sem grandeza, e em 1872 elevado a visconde do Bom Retiro com grandeza, logo após chegada do imperador da viagem ao exterior em que Couto Ferraz integrou a comitiva. ${ }^{47}$ Confirmava-se, mais uma vez, o alto apreço do imperador por Couto Ferraz.

A partir de entáo Bom Retiro passou a se dedicar também a atividades como a presidência do Imperial Instituto Fluminense de Agricultura (1865 a 1886), a vice-presidência e presidência do Instituto Histórico e Geográfico Brasileiro (1865-1876 e 1876-1886, respectivamente), à Associação Brasileira Protetora da Infância Desamparada, criada em 1883 e de cuja diretoria fundadora foi membro, ${ }^{48}$ além de outras em que participou como sócio, como

\footnotetext{
${ }^{42}$ Ibidem, p. 813.

${ }^{43}$ BARMAN, Roderick. O imperador cidadão. São Paulo: Unesp, 2012, p. 223

${ }^{44}$ Segundo José Murilo de Carvalho, O Conselho de Estado era a "cabeça do governo", e ser conselheiro era cargo almejado pelos políticos de carreira e restrito àqueles que se haviam destacado na vida pública, função de escolha quase particular do imperador.

${ }^{45}$ Frase famosa do senador José Thomaz Nabuco de Araújo. In: NABUCO, Joaquim. Um estadista do império, op. cit., p. 1102.

${ }^{46}$ MARTINS, Maria Fernanda Vieira. A velha arte de governar: um estudo sobre política e elites a partir do Conselho de Estado (1842-1889). Rio de Janeiro: Arquivo Nacional, 2007, p. 393.

${ }^{47}$ Couto Ferraz foi membro da comitiva imperial em duas viagens ao exterior: a primeira, em 1871, durou 10 meses e, a segunda, em 1876, um ano e seis meses.

${ }^{48}$ SCHUELER, Alessandra Frota Martinez de. A “infância desamparada” no Asilo Agrícola de Santa Isabel: instrução rural e infantil (1880-1886). Educação e Pesquisa, São Paulo, v. 1, n. 26, p. 119-133, 2000. p. 121.
} 
a Sociedade Amante da Instrução, a Sociedade Propagadora das Belas-Artes e a Sociedade Auxiliadora da Indústria Nacional. A condição de senador, conselheiro de Estado e amigo íntimo de Pedro II dava a Couto Ferraz a possibilidade de transitar entre as diferentes esferas do poder, e tal fato propicia elementos relevantes para o estudo das entidades em que ele esteve à frente. Afinal, nada mais facilitador para instituiçôes que subsistiam de verbas do Estado do que a aproximação com o mais alto mandatário do país.

A maneira com que Couto Ferraz exerceu o comando nessas instituições revela, também, sua concepção de Estado e, indiretamente, a do imperador, conforme veremos adiante. Tomemos como exemplo a trajetória do Imperial Instituto Fluminense de Agricultura (IIFA), que durante 21 anos esteve sob sua direção. Órgão de caráter privado e criado por membros do Estado, proprietários rurais e homens das ciências, seus objetivos eram o melhoramento da agricultura com propostas de mudanças na rotina da lavoura, de incorporação de princípios científicos e de introdução de máquinas e instrumentos agrícolas nas atividades rurais. O IIFA era constituído pelo Jardim Botânico da Lagoa Rodrigo de Freitas (atual Jardim Botânico do Rio de Janeiro); a Fazenda Normal, que funcionava como espaço para a prática de experimentaçóes técnico-científicas; o Asilo Agrícola, que acolhia órfãos desvalidos; e a Revista Agrícola, de periodicidade trimestral e destinada à divulgação de temas relacionados com as atividades da lavoura.

O projeto era ambicioso e coadunava-se com as aspirações das elites do império, em busca do ideal de progresso e civilização e sintonizadas com a produtividade agrícola na Europa e nos Estados Unidos. Entretanto, sua execução era tarefa difícil em um país escravocrata com terras de pequeno valor e o projeto não alcançou a magnitude desejada ou, ainda, foi grande a distância entre as metas institucionais e seu resultado, configurando-se mais como uma proposta prospectiva. A atuação do IIFA foi marcada pela pouca visibilidade na sociedade. Decerto o apoio irrestrito do imperador foi fundamental para que a instituição tivesse garantida sua sobrevivência por 29 anos. Por outro lado, a presença do monarca em quase todas as reunióes do IIFA pode ter sido um fator inibitório de opinióes, sobretudo as adversas, o que talvez contribuiu para a paralisia que, com o tempo, tomou conta da instituição.

Não cabe aqui aprofundar a análise sobre o IIFA, ${ }^{49}$ mas sim destacá-lo como bom exemplo de um modus operandi comum a Couto Ferraz e o imperador (que tudo orientava e acompanhava), o de alijar a classe política em projetos dessa natureza fundamentando-os, antes, em conceitos e experiências advindos de outros países e assim resguardá-los de intrigas partidárias ou outras formas de disputas.

O esforço de Couto Ferraz na fundação de instituições imperiais e seu afastamento da vida partidária coadunavam-se com o pensamento do monarca, que assim se expressou em seu diário ao referir-se à criação do IIFA:

\footnotetext{
${ }^{49}$ Sobre o IIFA, ver o livro da autora deste artigo: BEDIAGA, Begonha. Marcado pela própria natureza: o Imperial Instituto Fluminense de Agricultura - 1860 a 1891. Rio de Janeiro: FGV, 2014.
} 
11 [de julho de 1862] (...) o Instituto [IIFA] pode ir fazendo desde já em ponto pequeno, no sentido da combinação das duas ideias, dele [Guilherme Schüch Capanema] que é a minha, podendo-se facilmente obter auxílio do Estado, sem o inconveniente da influência política, que tanto tem estorvado os melhores pensamentos, desde que virem que o Instituto faz alguma coisa..$^{50}$

Observa-se, no trecho, a interferência do monarca na concepção do IIFA e nas experiências que ali se realizariam. A intenção de preservar a instituição de interesses políticos partidários pode parecer ingênua, mas revela de certo modo uma de suas estratégias no exercício do Poder Moderador, ao lançar mão de sua autoridade para angariar aportes financeiros do Estado visando o funcionamento de uma instituição privada com propósitos que se coadunavam com o governo imperial:

Tem havido progresso mas como a nossa política e administração correspondente é para desesperar a lida em que andam os que querem ver o Brasil caminhar mais depressa.

Eu vejo um remédio; porém é necessário que haja mais de uma andorinha que arrisque-se a ficar depenada.

Adeus! Quando poderemos ter um bom voo! ${ }^{51}$

A correspondência espelha também outro aspecto da ligação entre ambos, igualmente expresso no diário de Pedro II: as ingerências do monarca nos projetos de instituiçóes privadas em que Couto Ferraz esteve envolvido. Diretrizes no ensino agrícola, nomeaçóes de membros das diretorias, lavouras que deveriam entrar em fase de experimentação, detalhes sobre orçamento e verbas do governo eram temas frequentes, a evidenciar que Couto Ferraz solicitava constantemente o parecer do monarca acerca de suas decisóes. Na carta em que anexa o relatório do IIFA, observa: "Digne-se V.M.I examiná-lo e corrigi-lo antes da última impressão." Em outra, cita nomes para o Conselho Fiscal do IIFA que irá submeter à aprovação em Assembleia da instituição, mas salienta "tudo isto no caso de V.M.I. não ordenar o contrário". 52

Em geral a imprensa referia-se a Couto Ferraz associando-o ao monarca. Um exemplo a destacar revela a ironia de José de Alencar sobre o título nobiliárquico de Bom Retiro e a comparação com Dom Quixote e Sancho Pança:

A propósito, acode-me uma reflexão acerca de títulos. Parece que eles também são antíteses, como os nomes.

\footnotetext{
${ }^{50}$ BEDIAGA, Begonha (Org.). Diário do imperador d. Pedro II. Petrópolis: Museu Imperial, 1999. 1 CD-ROM. Pasta Original 09, arquivo D09164.

${ }^{51}$ Biblioteca Nacional do Rio de Janeiro. Carta de d. Pedro II para o Visconde de Bom Retiro. Rio de Janeiro, 29/11/1875. Notação SM I-35, 8, 89. In: BARMAN, Roderick. O imperador cidadão, op. cit., 2012, p. 386.

${ }^{52}$ Respectivamente: Museu Imperial. Arquivo Histórico. Arquivo POB, maço 167, doc. 7712. Cartas de Luís Pedreira do Couto Ferraz a d. Pedro II, s/d [D55] e 21/2/1874 [D46].
} 
Crismar-se um homem de barão ou Visconde de Bom Retiro; arranjar um brasão apropriado; e em vez do remanso tranquilo onde goze as delícias do Deus nobis hac oftía fecit [Deus concedeunos este descanso]; empunhar a mala e ir-se pelo mundo afora sem descanso, à semelhança daquele meu amigo Sancho; é sem dúvida um capricho da fortuna.

Espera-se que o ilustre Visconde na primeira fornada de fidalgos tome o exemplo do sr. de Jaguary; e reclame para si o título muito mais adequado de marquês da Boa Viagem. ${ }^{53}$

Nos últimos dez anos de vida de Couto Ferraz, a saúde debilitada forçou-o a longos períodos de repouso, afastando-o de seus afazeres. Nessas ocasiōes escrevia inúmeras cartas a Pedro II sobre assuntos variados e desculpava-se por sua ausência em audiências no palácio ou em atividades no IIFA, Senado, IHGB e outros. Nas respostas, Pedro II o consolava e declarava sentir falta do convívio com o amigo: "Muito tenho que conversar com você, que tomara já haver restabelecido sobretudo pela afeição que sempre lhe tenho. Seu amigo P." 54

Por ocasiáo do falecimento de Couto Ferraz, em 1886, os jornais noticiaram que Pedro II, muito emocionado, afirmou: "É a consciência mais pura que tenho conhecido."

\section{A Gazeta da Tarde assim se referiu a Couto Ferraz:}

Havia, no Visconde do Bom Retiro, duas entidades bem diversas: uma tangível, brilhante de talento, de argúcia, de profunda abnegação aparente, ou real, e por isso mesmo estimável; outra impalpável, misteriosa, espécie de espírito puro de que o imperador era médio e que só por este se manifestava. (...) Quanto a sua parte de sua individualidade resta a história dizer sobre ela, perguntando-lhe como se aproveitou da sua influência sobre o imperador para tirar proveito para o progresso moral da pátria..$^{56}$

Observe-se que o autor da nota, sem conseguir apontar as alegadas vantagens obtidas por Couto Ferraz na convivência estreita com o imperador, delegou à história essa tarefa.

A Revista Ilustrada, conhecida pela posição crítica ao governo e ao imperador, foi benevolente com Couto Ferraz no obituário que publicou:

De sua influência benéfica na política, aplacando as excitações partidárias da sua missão no mundo das letras, contribuindo para a fundação de sociedades e institutos sábios, dizem-se maravilhas, e, mais do que ninguém, nós pensamos que isto lhe faz muita honra. Mas, o traço

\footnotetext{
${ }^{53}$ O Protesto. Rio de Janeiro: Imprensa Industrial, 1877, p. 13. Jornal publicado por José de Alencar, seu irmão, Leonel Martiniano de Alencar e Felix Ferreira. Disponível em: <http://www2.senado.leg.br/bdsf/ item/id/185635>. Acesso em: 30 ago. 2016.

${ }^{54}$ LACOMBE, Lourenço Luiz. Os chefes do executivo fluminense, op. cit., 1963, p. 78.

${ }_{55} \mathrm{O}$ Visconde de Bom Retiro: diversos discursos, cartas e recortes de jornais acerca do seu falecimento. Gazeta de Notícias. Revista Agrícola, v. 17, n. 3, p. 134, set. 1886.

${ }^{56}$ Ibidem, p. 135.
} 
profundo que deixa na história, o Visconde do Bom Retiro, é a sua amizade, ininterrompida, durante 30 anos, com o imperador; e, de duas uma: ou o chefe do estado é muito refratário a influências alheias ou o nobre Visconde não teve grande ascendente sobre o seu amigo.

Em seguida, o autor da matéria critica a permanência da escravidão no país "durante 47 anos", então, o tempo da duração do reinado de Pedro II, e termina com mais elogios a Couto Ferraz: "Não sabemos, se foi o temperamento, ou os aborrecimentos, que isolaram do mundo o Visconde do Bom Retiro, dando-lhe um tom monástico, que se refletia em sua bondosa fisionomia." ${ }^{57}$

\section{Redes e clientelismo}

As fontes epistolares mostram que Couto Ferraz atendia a sua rede de sociabilidades e dela solicitava grande número de pedidos de empregos, cargos e todo tipo de auxílio. Quando havia conflito de interesses, esmerava-se em apaziguar os ânimos, embora nem sempre lograsse êxito, como demonstra numa carta ao marquês de Olinda: "Disse-me a respeito V.E. uma vez, que ninguém pode brigar comigo. Perdoe-me que lhe diga que isto não é exato. Muita gente tem infelizmente brigado comigo sem eu fazer por onde, ao menos intencionalmente" ${ }^{58}$

Após deixar o ministério, parecia convencido de que seus pedidos deviam continuar a ser atendidos e zangava-se perante negativas. Um exemplo foi o tom ríspido com que se dirigiu ao marquês de Olinda, que não atendera a uma solicitação de emprego aos cunhados. Apesar de não termos as cartas de resposta do marquês, é evidente o ressentimento de Couto Ferraz. Interessante no trecho a seguir é a alegação de que, quando ministro, esteve impedido de intervir, sob o risco de ser acusado de nepotismo:

V.E. tem muito bom coração - estima-me, e há de dar-me razão, conhecendo, que é muito duro - que durante o meu ministério nada pudesse fazer em benefício de meus cunhados, por isso mesmo, porque eram meus cunhados, e que, esperando poder conseguir para eles alguma coisa quando deixasse de ser ministro — nada posso fazer em seu favor, e ainda por cima fico mal no conceito deles, supóem, que não emprego todos os esforços para que consigam alguma coisa. ${ }^{59}$

\footnotetext{
${ }^{57}$ Revista Ilustrada, v. 11, n. 437, p. 2, 1886. Disponível em:<http://memoria.bn.br/DocReader/332747/3109>. Acesso em: 21 nov. 2016.

${ }^{58}$ Instituto Histórico e Geográfico Brasileiro. Arquivo Marquês de Olinda. Carta de Couto Ferraz ao marquês de Olinda 21/10, sem especificar o ano, [Rio de Janeiro]. Notação DL 213.73

${ }^{59}$ Instituto Histórico e Geográfico Brasileiro. Arquivo Marquês de Olinda. Carta de Couto Ferraz ao marquês de Olinda de 25/9/1857. Notação DL 213.73.
} 
Entretanto, Couto Ferraz parece ter faltado à verdade. Em discurso na Câmara, ${ }^{60}$ o deputado Joaquim Jerônimo Fernandes da Cunha, em defesa de José Antônio Saraiva, ${ }^{61}$ protestou contra os "manejos indecentes" que o opositor José Antônio de Magalhães Castro (cunhado de Couto Ferraz) utilizara para tentar vencer as eleiçôes. O deputado afirmara que o então ministro Couto Ferraz teria usado seu posto para constranger autoridades do distrito eleitoral. Uma vez que o discurso e o debate ultrapassam o âmbito deste artigo, destaco apenas uma das cartas de Couto Ferraz lidas no plenário pelo referido deputado, que esclarece a situação:

Exmo. Sr. em 14 de outubro.

Partindo para esse lugar, meu cunhado o Sr. Dr. José Antônio de Magalhães Castro, tomo a liberdade de recomenda-lo a V.S. com maior empenho. Faço confiando muito em sua bondade, e pelas notícias que pelo mesmo meu cunhado tenho de suas excelentes qualidades (Nem conhece o sujeito a quem se dirige). ${ }^{62}$ Além disto a posição de parentesco, e intimidade em que vivo com este senhor, a quem prezo e estimo como a meu irmão, tira da minha recomendação toda ideia de intervenção política, e de caráter ministerial. Faço, pois, sem hesitação. Como tal S.S. a receberá, e confio que fará tudo quanto puder e quanto depender de seus justos esforços, e dos seus amigos, a bem do dito senhor. Acredite que me confessarei sempre grato, assinandome com muito prazer. De V.S. atento venerador e criado,

Luiz Pedreira do Couto Ferraz.

Nota-se, na carta, a forma sutil com que Couto Ferraz intervém a favor do cunhado, ao afirmar os laços familiares e de amizade que motivam o pedido ao mesmo tempo que alude, ainda que pela negação, a seu alto status no governo ("Além disto a posição de parentesco, e intimidade em que vivo com este senhor, a quem prezo e estimo como a meu irmão, tira da minha recomendação toda ideia de intervenção política, e de caráter ministerial"). A mesma sutileza está presente ao enunciar o pacto característico do clientelismo político: à gratidão correspondia uma dívida que poderia ser cobrada — e a de um ministro não era algo a desconsiderar ("Acredite que me confessarei sempre grato").

Em outras ocasiōes Couto Ferraz também recorreria à sua alta posição para intervir a favor da família, como o apoio a pleitos de seu irmão João Pedreira do Couto Ferraz, secretário do Supremo Tribunal de Justiça, ou em relação aos quatro cunhados quando solicitou para eles ascensão funcional em cargos do Estado e outros benefícios. ${ }^{63}$

${ }^{60}$ Sessão do dia 30/4/1857, cuja ata foi publicada no Jornal do Comércio em 19/6/1857. Disponível em: <http://memoria.bn.br/DocReader/364568_04/11512>. Acesso em: 22 set. 2016.

${ }^{61}$ José Antônio de Saraiva (Conselheiro Saraiva), eleito deputado na região de Juazeiro, Bahia. Jornal do Comércio. Rio de Janeiro, 19/6/1857. Disponível em: <http://memoria.bn.br/DocReader/364568_04/11512>. Acesso em: 10 set. 2016.

${ }^{62}$ Os parêntesis e a fonte em itálico encontram-se no original da ata.

${ }^{63}$ Ver também: Museu Imperial/IBRAM. Carta [s/d] de Luís Pedreira do Couto Ferraz, Visconde do Bom Retiro, a d. Pedro II. Arquivo POB, maço 191, doc. 8716. Comenta o falecimento do cunhado e solicita 


\section{Couto Ferraz nos debates sobre a escravidão}

Nas discussóes acerca do projeto da Lei do Ventre Livre, Couto Ferraz esteve à frente de uma petição que tratava da indenização, ao proprietário, pela liberdade dos filhos de escravas nascidos após a aprovação da lei. Seus argumentos foram expostos em diversos fóruns, mas é necessário nos debruçarmos, antes, sobre esse projeto de lei e suas principais controvérsias.

Nabuco, Carvalho ${ }^{64}$ e outros autores afirmam que a proposta de libertar do cativeiro as crianças de escravas nascidas a partir de uma determinada data contou com o apoio pessoal de Pedro II, que na Fala do Trono de 1867 solicitou ao Legislativo o debate do tema. ${ }^{65}$ Um ano antes, no Conselho de Estado, José Antônio Pimenta Bueno, visconde e posteriormente marquês de São Vicente, apresentara o primeiro projeto para discussão. Nos debates travados entre os conselheiros, Couto Ferraz notabilizou-se como defensor do direito à propriedade do ventre da escrava pelo senhor. De acordo com Nabuco, Bom Retiro “(...) faz vingar indiretamente o princípio da indenizaçâo ao senhor pelo filho da escrava nascido livre, uma vez criado. Sustenta fortemente, com todas as suas consequências, o partus sequitur ventrem". ${ }^{66}$

Os favoráveis ao Ventre Livre argumentavam que o projeto era uma opção segura para o caminho rumo à aboliçáo da escravidáo. Aqueles que se opunham consideravam que a medida levaria os proprietários rurais à falência, porque ocasionaria falta de mão de obra para as lavouras, além de incentivar a desobediência dos escravos, o que mergulharia o país no caos político e econômico.

O presidente do Conselho de Ministros, visconde do Rio Branco, teve papel fundamental na conduçáo do debate entre os membros da Câmara e do Senado. O tema instalou uma desorganização entre os partidos políticos, que não chegaram a um consenso para se posicionar em bloco. Ao fim, a Lei do Ventre Livre contou com o apoio de uma ala dos Conservadores e da maioria dos Liberais.

um emprego para o sobrinho; Memorial Denis Bernardes/UFPE. Carta [s/d] enviada por Manoel Jesuíno Ferreira [cunhado do Bom Retiro] para o conselheiro João Alfredo Correia de Oliveira. Faz referência à execução de certo trabalho que lhe fora confiado por João Alfredo, pede realizar o que lhe foi prometido, conforme disse ao Visconde do Bom Retiro. Disponível em: <http://repositorio.ufpe.br:8080/xmlui/handle/123456789/15629>. Acesso em: 22 set. 2016.

${ }^{64}$ NABUCO, Joaquim. Um estadista do império; CARVALHO, José Murilo de. A construção da ordem: a elite política imperial, op. cit.

65 "O elemento servil no Império não pode deixar de merecer oportunamente a vossa consideração, provendo-se de modo que, respeitada a propriedade atual, e sem abalo profundo em nossa primeira indústria, a agricultura, sejam atendidos os altos interesses que se ligam à emancipação.” A Abolição no Parlamento: 66 anos de luta (1823-1888). Brasília: Senado Federal, 1988, p. 269. v. 1.

${ }^{66}$ NABUCO, Joaquim. Um estadista do império, p. 704. 
Couto Ferraz declarava-se favorável ao fim da escravidão, porém sem entusiasmo e bastante apreensivo, conforme se lê em parecer de sua autoria: ${ }^{67}$ "a necessidade de se ir abrindo o caminho e preparando terreno para gradual e prudentemente chegar-se ao fato inevitável da emancipação dos escravos". Esclarecia ele que o principal motivo para avançar na questão do elemento servil era a "pressão moral do mundo civilizado", que o assunto "no Brasil é muito mais melindroso, do que o foi em qualquer das nações que têm tido escravos", sobretudo por conta do avultado número de cativos no país e a falta de mão de obra livre. Portanto, era preciso muita cautela mediante a desorganização que tal medida poderia acarretar.

Com o propósito de reforçar suas preocupaçóes, acrescentou em seu parecer uma análise dos processos abolicionistas em diversos países e dava o exemplo:

No próprio Estados Unidos o golpe ${ }^{68}$ da emancipação, apesar de sangrento, partiu de Estados fortes e poderosos, como são os do Norte, onde não havia escravos, e que dispunham de grandes recursos para contrabalançar o grande abalo, que sofreram e continuam a sofrer os estados do Sul.

Concluía afirmando que no Brasil era diferente, porque "o trabalho produtivo das terras depende profundamente dos escravos”. Deixava claro o temor pela crise que a emancipação sem controle poderia acarretar e enfatizava:

Não dissimularei, contudo, que faz grande peso em meu ânimo - a consideração dos inconvenientes, e até o perigo que podem resultar no futuro, em declarar-se livre e chamar-se para o seio da nossa sociedade política tão grande massa de pessoas que se trata de educar e instruir; colocando ao mesmo tempo em condiçóes de tão notável inferioridade relativa ao geral dos cidadãos brasileiros, quais têm eles de ser iguais perante a lei!!! 99

Não há, no parecer, críticas à escravidão, mas sim aos abolicionistas. Couto Ferraz manifestava-se de fato como porta-voz dos proprietários rurais e diante da iminência da abolição por etapas tentava garantir aos donos de escravos o menor prejuízo possível, com medidas como a indenização que propunha.

Causa estranheza a posição crítica do alter ego do imperador a um projeto por esse apoiado. Porém, pode-se conjecturar que Couto Ferraz, em consonância com Pedro II, buscava amenizar um confronto inevitável e, assim, preservar a imagem do monarca, sobretudo perante os grandes proprietários rurais que tinham sua produção baseada na mão de obra

\footnotetext{
${ }^{67}$ Museu Imperial/IBRAM. Arquivo POB, maço 160, doc. 7390. "Parecer do conselheiro de Estado Luís Pedreira do Couto Ferraz, Visconde do Bom Retiro - Tratando sobre o projeto do elemento servil. Secretaria dos Negócios do Império, 31/01/1871”. 12 páginas manuscritas.

${ }^{68}$ Idem. Sublinhado no original.

${ }^{69}$ Idem. Sublinhado no original.
} 
escrava. Lembremo-nos ainda que, desde as eleiçóes da década de 1840, Couto Ferraz mantinha estreitos vínculos com os fazendeiros da província fluminense - principais opositores à lei —, onde iniciara sua carreira política. Assim, ao defender que "os proprietários do ventre escravo são incontestavelmente senhores dos filhos do mesmo ventre", ${ }^{70}$ seu papel pode ter sido o de apaziguar os ânimos. Reforça essa hipótese a interpretação de Carvalho, que afirma ter sido o Ventre Livre o início do "divórcio entre o rei e os barôes que viram a lei como loucura dinástica". ${ }^{71}$

É possível supor que Bom Retiro tenha elaborado seu "Parecer acerca do elemento servil" de forma independente do imperador, com a intenção de adequar a lei ao formato jurídico que considerava correto. Contudo, a tese da consonância com o imperador e com seus próprios interesses ganha ainda mais força com o fato de Couto Ferraz não ter comparecido à votação da lei em setembro de 1871 por se encontrar desde maio em viagem ao exterior, na comitiva que acompanhava Pedro II - o que demonstra que a amizade entre ambos se mantinha apesar das eventuais divergências.

Não obstante a forte pressão internacional pela aprovação da Lei do Ventre Livre, as démarches foram longas e, em alguns momentos, tensas. Talvez influenciado por esse clima, Couto Ferraz radicalizou e surpreendentemente condicionou seu voto favorável à aceitaçáo da cláusula de indenização. Sua proposta foi defendida por Paranhos e incluída no texto final da lei.

No contexto de animosidade em que ocorreram os debates sobre o Ventre Livre, compreende-se melhor os motivos que levaram Couto Ferraz a negar o convite do visconde de São Vicente para assumir o Ministério da Justiça, em 1869. Nabuco afirma que Bom Retiro alegou não se encontrar em boas condiçóes de saúde e que Pedro II teria insistido muito até que, em face das negativas disse, "meio agastado: 'Bom! Contra o egoísmo, não tenho argumentos.' Não era egoísmo, porém; era a atrofia da ambição; o retraimento, a timidez dos solitários." 72 Poderíamos acrescentar que a recusa de Couto Ferraz se deu também pela repulsa ao conflito.

\section{Conclusão}

Trazer Luís Pedreira do Couto Ferraz, visconde do Bom Retiro, à cena do Segundo Reinado foi uma tarefa árdua, especialmente em virtude do desaparecimento dos documentos que ele acumulou em mais de 40 anos de vida pública. O fato parece incomum diante do cuidado, por parte dos descendentes de personagens vinculados ao poder, em preservar os

\footnotetext{
${ }^{70}$ Idem.

${ }^{71}$ CARVALHO, José Murilo de. A construção da ordem: a elite política imperial, op. cit., p. 297.

${ }^{72}$ NABUCO, Joaquim. Um estadista do império, p. 823.
} 
registros que comprovam seus laços de sangue e lhes outorgam prestígio social. Porém o descarte dos documentos pessoais de Couto Ferraz soa coerente com sua personalidade e sua vida pública, ambas pautadas pela discrição. É de supor, inclusive, que tal característica seja em boa parte responsável pelas raras menções a ele na historiografia.

Pedro II demonstrava não possuir amigos, receoso que era de ser acusado de ter protegidos. O imperador registrou, em seu diário, o desejo de reinar sem favoritismos: "Não tenho tido, nem tenho validos, caprichando mesmo em evitar qualquer acusação a tal respeito, sobretudo quanto a validas. Dizem que por esse nímio escrúpulo não poderei criar amigos; melhor, não os terei falsos quando os haja granjeado." 73

Couto Ferraz foi uma das poucas exceçóes a essa postura do monarca e decerto foi o mais próximo entre aqueles que gozaram de sua confiança. Nabuco afirma que Bom Retiro foi o "mais leal, verdadeiro e discreto amigo do imperador" ${ }^{74}$ mas ressalta:

A confiança, a confidência do Imperador era, para a luta política, quase inibitória. Era um privilégio, mas que participava da natureza do poder que refletia: da neutralidade própria da realeza. Ser palaciano era assim ao mesmo tempo uma força e uma fraqueza: força para a inspiração, a influência, as posiçóes auxiliares, encobertas; fraqueza, incapacidade para a posição responsável, para o comando em chefe. ${ }^{75}$

Couto Ferraz buscou alijar-se, de forma quase obstinada, dos embates políticos. Tal comportamento é bem exemplificado no conselho que deu a Zacarias de Góes e Vasconcellos, em um debate no Senado: "Faça como eu, cale-se."76 Nabuco mais uma vez nos ajuda a revelar esse personagem, ao observar que ele "talvez por não saber negar-se é que se ocultava e não apreciava o poder" ${ }^{77}$ À parte o exagero dessa afirmação, pois desde sempre Couto Ferraz esteve no poder e trabalhou com afinco para nele permanecer, talvez Nabuco se referisse às muitas ocasióes em que nosso personagem recusou cargos de ministro e até mesmo de presidente do Conselho de Ministros, optando por outros percursos — os quais, todavia, não os afastaram do cerne político do país até a sua morte, em 1886.

A análise de sua trajetória permite depreender que ele foi um hábil e influente personagem da elite política imperial e destacou-se de forma mais evidente na execução das reformas jurídico-administrativas do país, fossem aquelas debatidas na esfera política ou as advindas de projetos do imperador, a exemplo de seu papel nas reformas do ensino. Em sua

\footnotetext{
${ }^{73}$ BEDIAGA, Begonha (Org.). Diário do imperador d. Pedro II, op. cit. Pasta Original 09, arquivo D09002, $31 / 12 / 1861$

${ }^{74}$ NABUCO, Joaquim. Um estadista do império, p. 167.

${ }^{75}$ Ibidem, p. 822.

${ }^{76}$ Citado em OTTONI, Christiano Benedicto. Emancipação dos escravos, 1883, p. 8. Acesso em: 15 jul. 2016. Disponível em: <http://www2.senado.leg.br/bdsf/item/id/179447>.

${ }^{77}$ NABUCO, Joaquim. Um estadista do império, p. 167.
} 
trajetória pública, Couto Ferraz agiu norteado pelas ideias de centralização do Estado e da manutenção da autoridade do monarca, alinhadas à intenção de inserir o Brasil no patamar da civilização europeia.

\section{Fontes documentais}

Arquivo Público do Estado do Espírito Santo. Livro das Leis do Espírito Santo. Regulamento das escolas de primeiras letras da província do Espírito Santo, promulgado em 20 de fevereiro de 1848 e aprovado provisoriamente pela Lei n. 6 de maio do mesmo ano.

BRASIL. Congresso. Senado Federal. Secretaria Especial de Editoração e Publicações. A Abolição no Parlamento: 66 anos de luta (1823-1888). Brasília: Senado Federal, 1988. v. 1. . Coleção de leis. Decreto n. 630 de 17/9/1851.

. Coleção de Leis. Decreto n. 64 de 22 de outubro de 1836.

- Congresso. Câmara dos Deputados. Centro de Documentação e Informação. Nominata de deputados brasileiros constituintes: 1823. [Brasília], s.d. (folhas datilografadas).

- Congresso. Câmara dos Deputados. Centro de Documentaçãa e Informação. Nominata de deputados brasileiros 1ํㅡㄴ Legislatura: [Império]: 1826-1829. [Brasília], s.d. (folhas datilografadas).

- Congresso. Câmara dos Deputados. Centro de Documentação e Informação. Nominata de deputados brasileiros 7̣ Legislatura: Império: 1848. [Brasília], s.d. (folhas datilografadas).

- Congresso. Câmara dos Deputados. Centro de Documentação e Informação. Nominata de deputados brasileiros 8aㅡ Legislatura: Império: 1849-1852. [Brasília], s.d. (folhas datilografadas).

- Congresso. Câmara dos Deputados. Centro de Documentação e Informação. Nominata de deputados brasileiros 9a Legislatura: Império: 1853-1856. [Brasília], s.d. (folhas datilografadas).

Diário do Rio de Janeiro. Rio de Janeiro, 23/7/1847, p. 2. Disponível em: <http://memoria. bn.br/DocReader/cache/895608108287/I0031268-2Alt=002462Lar=001528LargOri=00 4224AltOri=006806.JPG>. Acesso em: 27 out. 2016.

IBRAM. Museu Imperial. Arquivo POB, maço 160, doc. 7390. "Parecer do conselheiro de Estado Luís Pedreira do Couto Ferraz, Visconde do Bom Retiro - Tratando sobre o projeto do elemento servil. Secretaria dos Negócios do Império, 31/01/1871”. 12 páginas manuscritas.

. Museu Imperial. Arquivo Histórico. Arquivo POB, maço 167, doc. 7712. Cartas de Luís Pedreira do Couto Ferraz a d. Pedro II, 21/2/1874 [D46] e s/d [D55]. 
. Museu Imperial. Arquivo Histórico. Arquivo POB, maço 169, doc. 7741. Carta de Luís Pedreira do Couto Ferraz a d. Pedro II, de 21/2/1874.

. Museu Imperial. Carta [s/d] de Luís Pedreira do Couto Ferraz, Visconde do Bom Retiro, a d. Pedro II. Arquivo POB, maço 191, doc. 8716.

. Museu Imperial/IBRAM. Arquivo POB, maço 160, doc. 7390, "Parecer do conselheiro de Estado Luís Pedreira do Couto Ferraz, Visconde do Bom Retiro - Tratando sobre o projeto do elemento servil. Secretaria dos Negócios do Império, 31/01/1871”. 12 páginas manuscritas.

IHGB. Arquivo Marquês de Olinda. Carta de Luís Pedreira do Couto Ferraz ao marquês de Olinda 21/10 [ano não informado], [Rio de Janeiro]. Notação DL 213.73

. Arquivo Marquês de Olinda. Carta de Luís Pedreira do Couto Ferraz ao marquês de Olinda de 25/9/1857. Notação DL 213.73

IPHAN. Biblioteca Nacional do Rio de Janeiro. Carta de d. Pedro II para o Visconde de Bom Retiro. Rio de Janeiro, 29/11/1875. Notação SM I-35, 8, 89. In: BARMAN, Roderick. O imperador cidadão. São Paulo: Unesp, 2012, p.386.

Biblioteca Nacional. Seção de Manuscritos: "Requerimento encaminhado ao Ministério do Império, solicitando ser nomeado para uma das cadeiras vagas na academia de São Paulo”, 1839. Localização: C-0478,015 n. 001.

O Protesto. Rio de Janeiro: Imprensa Industrial, 1877. Disponível em: <http://www2. senado.leg.br/bdsf/item/id/185635>. Acesso em: 30 ago. 2016.

Jornal do Comércio. Rio de Janeiro, 29/11/1844. Disponível em: <http://memoria.bn.br/ DocReader/364568_03/7065>. Acesso em: 9 out. 2016.

Jornal do Comércio. Rio de Janeiro, 19/6/1857. Disponível em: <http://memoria.bn.br/ DocReader/364568_04/11512>. Acesso em: 10 set. 2016.

Jornal do Comércio. Rio de Janeiro, 11/12/1857. Disponível em: <http://memoria.bn.br/ DocReader/364568_04/12230>. Acesso em: 29 set. 2016.

Jornal do Comércio. Rio de Janeiro, 19/5/1858. Disponível em: <http://memoria.bn.br/ DocReader/364568_04/12857>. Acesso em: 29 set. 2016.

Relatório do presidente da província do Espírito Santo, o doutor Luiz Pedreira do Couto Ferraz, na abertura da Assembleia Legislativa Provincial no dia 23 de maio de 1847. Rio de Janeiro, Typographia do Diário de N.L. Vianna, 1848.

Repositório institucional da UFPE. Memorial Denis Bernardes. Coleção conselheiro João Alfredo Correia de Oliveira. Disponível em: <http://repositorio.ufpe.br:8080/xmlui/ handle/123456789/15629>. Acesso em: 22 set. 2016.

Revista Agricola do Imperial Instituto Fluminense de Agricultura. O Visconde de Bom Retiro: diversos discursos, cartas e recortes de jornais acerca do seu falecimento, v. 17, n. 3, p. 134135 , set. 1886 . 
Revista Ilustrada, v. 11, n. 437, p. 2, 1886. Disponível em: <http://memoria.bn.br/ DocReader/332747/3109>. Acesso em: 21 nov. 2016.

\section{Referências bibliográficas}

BARMAN, Roderick. O imperador cidadão. São Paulo: Unesp, 2012.

BEDIAGA, Begonha (Org.). Diário do imperador d. Pedro II. Petrópolis, RJ: Museu Imperial, 1999. CD-ROM.

Carlos Humberto P. Corrêa. A presidência de província no império. ANPUH - XXII SIMPÓSIO NACIONAL DE HISTÓRIA. João Pessoa, 2003.

Carta [s/d] enviada por Manoel Jesuíno Ferreira [cunhado do Bom Retiro] para o conselheiro João Alfredo Correia de Oliveira. Faz referência à execução de certo trabalho que lhe fora confiado por João Alfredo, pede realizar o que lhe foi prometido, conforme disse ao Visconde do Bom Retiro.

CARVALHO, José Murilo de. A construção da ordem: a elite política imperial. Rio de Janeiro: UFRJ/Relume-Dumará, 1996.

CASTANHA, André P. O Ato Adicional de 1834 e a instrução elementar no império: descentralização ou centralização? Tese (doutorado) Universidade de São Carlos, São Carlos, 2007.

DEL PRIORE, Mary. Biografia: quando o indivíduo encontra a história. Topoi. Revista de História, Rio de Janeiro, v. 10, n. 19, p. 7-16, 2009.

EDLER, Flavio Coelho. As reformas do ensino médico e a profissionalização da medicina da corte do Rio de Janeiro: 1854-1884. Dissertação (mestrado) — Departamento de História, Universidade de São Paulo, São Paulo, 1992.

FERRAZ, Paula Ribeiro. O Gabinete da Conciliação: atores, ideias e discursos (18481857). Dissertação (mestrado em História) — Programa de Pós-Graduação em História, Universidade Federal de Juiz de Fora, 2013.

GAUDIO, Eduardo Vianna. Couto Ferraz e os regulamentos de educação na província do Espírito Santo - 1848 e 1861. VIII CONGRESSO BRASILEIRO DE HISTÓRIA DA EDUCAÇÃO, 2015, Maringá. Anais.

GONDRA, Jorge Gonçalves; TAVARES, Pedro Paulo Hausmann. A instrução reformada: ações de Couto Ferraz nas províncias do Espírito Santo, Rio de Janeiro e na Corte Imperial. CONGRESSO BRASILEIRO DE HISTÓRIA DA EDUCAÇÃO, 3.: A EDUCAÇÃO ESCOLAR EM PERSPECTIVA HISTÓRICA, 2004, Curitiba. Anais. Curitiba: Adivan High Tech Tecnologia Digital, 2004. v. 1.

HOLANDA, Sergio Buarque de. Capitulos de história do império. São Paulo: Companhia das Letras, 2010. 
LACOMBE, Lourenço Luiz. Os chefes do executivo fluminense. Petrópolis, RJ: Museu Imperial, 1973, p. 20.

LIMEIRA, Aline Moraes de; SCHUELER, Alessandra Frota Martinez de. Ensino particular e controle estatal: a Reforma Couto Ferraz (1854) e a regulação das escolas privadas na corte imperial. Revista Histedbr, n. 32, p. 48-64, 2008.

LOPES, Maria Margaret. O Brasil descobre a pesquisa cientifica: os museus e as ciências naturais no século XIX. São Paulo: Hucitec, 2009.

LORIGA, Sabina. O pequeno X: da biografia à história. Belo Horizonte: Autêntica, 2011.

LYRA, Heitor. História de dom Pedro II: 1825-1891. Belo Horizonte: Itatiaia, 1977.

MARTINS, Maria Fernanda Vieira. A velha arte de governar: um estudo sobre política e elites a partir do Conselho de Estado (1842-1889). Rio de Janeiro: Arquivo Nacional, 2007. MATTOS, Ilmar Rohloff de. O tempo Saquarema. São Paulo: Hucitec, 1994.

NABUCO, Joaquim. Um estadista do império. Rio de Janeiro: Topbooks, 1997.

NOGUEIRA, Almeida. A academia de São Paulo: tradiçóes e reminiscências. São Paulo: [Typographia Vanorden], 1907.

OTTONI, Christiano Benedicto. Emancipação dos escravos. Rio de Janeiro: Typographia Nacional, 1883. Disponível em: <http://www2.senado.leg.br/bdsf/item/id/179447>. Acesso em: 15 jul. 2016.

PÁDUA, José Augusto. Um sopro de destruição: pensamento político e crítica ambiental no Brasil escravista, 1786-1888. Rio de Janeiro: Zahar, 2002.

. Flora e nação. In: MARTINS, Ana Cecília (Org.). Flora brasileira: história \& arte \& ciência. Rio de Janeiro: Casa da Palavra, 2009, p. 92-128.

PONTES, Vinicius Liorde. A Reforma Couto Ferraz e o estabelecimento de uma direção para a instrução primária e secundária no Império do Brasil. Dissertação (mestrado) — Departamento de História, PUC, Rio de Janeiro, 2009.

RAFFARD, Henri. Apontamentos acerca de pessoas e cousas do Brasil. Revista do Instituto Histórico e Geográfico Brasileiro, Rio de Janeiro, t. 61, parte 2, p. 438, 1899.

SACRAMENTO BLAKE, Augusto Victorino Alves. Dicionário bibliográfico brasileiro. Rio de Janeiro: Imprensa Nacional, 1902. 7 v.

SCHUELER, Alessandra Frota Martinez de. A “infância desamparada” no Asilo Agrícola de Santa Isabel: instrução rural e infantil (1880-1886). Educação e Pesquisa, São Paulo, v. 1, n. 26, p. 119-133, 2000.

SISSON, Sebastién Auguste. Galeria dos brasileiros ilustres. Brasília, DF: Senado Federal, 1999. 